\title{
Phytoecdysones from the Roots of Achyranthes japonica Nakai and their Anti-atopy Activity
}

\author{
Ki Ohk Kim • Chang-Sub Ku $\cdot$ Min-Jin Kim • Yhun Jung Park $\cdot$ Hyung Won Ryu \\ - Hyuk-Hwan Song · Jung Hee Kim · Sei-Ryang Oh*
}

\section{우슬의 뿌리로부터 Phytoecdysones의 분리와 항 아토피 효과}

\author{
김기옥 · 구창섭 · 김민진 · 박윤정 · 류형원 · 송혁환 · 김정희 · 오세 량*
}

Received: 11 August 2014 / Accepted: 30 September 2014 / Published Online: 31 March 2015

(C) The Korean Society for Applied Biological Chemistry 2015

\begin{abstract}
The roots of Achyranthes japonica Nakai were extracted with $100 \%$ aqueous and concentrated subfraction was separated with ultra-performance liquid chromatography-based activity profiling. Three compounds were isolated from the subfraction 5 through the repeated prep- high performance liquid chromatography column chromatography. According to the results of physico-chemical and spectroscopic data including NMR and MS, the chemical structures of the compounds were determined as ecdysterone (1), 25S-inokosterone (2), and 25R-inokosterone (3). Three phytoecdysones were showed weak inhibitory activity for thymus and activation-regulated chemokine expression levels in tumor necrosis factor (TNF)- $\alpha$ plus IFN- $\gamma$ induced $\mathrm{HaCaT}$ cells, respectively. However, those compounds 1-3 were exhibited the most potent inhibition $(80-95 \%$ at $200 \mu \mathrm{g} / \mathrm{mL})$ against TNF- $\alpha$ expression levels in A23187 plus phorbol-myrisrate acetate-induced RBL-2H3 cells. As result, $100 \%$ aqueous extract of $A$. japonica has
\end{abstract}

K. O. Kim · Y. J. Park $\cdot$ H. W. Ryu $\cdot$ H.-H. Song $\cdot$ J. H. Kim · S.-R. Oh Natural Medicine Research Center, KRIBB, 30-Yeongudanji-ro, Ochangeup, Cheongwon 363-883, Republic of Korea

\section{C.-S. $\mathrm{Ku} \cdot \mathrm{M} .-\mathrm{J} . \mathrm{Kim}$}

Organic and Natural Product Research Center, Cotde Inc., Jeju Technopark, 4-8 Ara-1 dong, Jeju-City, Republic of Korea

*Corresponding author (S.-R. Oh: seiryang@kribb.re.kr)

K. O. Kim and C.-S. Ku contributed equally.

This is an Open Access article distributed under the terms of the Creative Commons Attribution Non-Commercial License (http://creativecommons. org/licenses/by-nc/3.0/) which permits unrestricted non-commercial use, distribution, and reproduction in any medium, provided the original work is properly cited. an excellent anti-atopy activity. It could be used to a large range of functional anti-atopy cosmetics.

Keywords Achyranthis Radix · anti-atopy · phytoecdysones

\section{서 론}

최근 산업화로 인한 대기오염, 서구화된 주거형태, 애완 동물 사육, 알레르기 유발물질과 접촉 증가, 모유 수유의 감소, 항생 제 사용이 증가함에 따라 아토피피부염 유병률이 증가하고 있 다(Wollenberg 등, 2000; Park과 Park, 2007). 아토피피부염은 환경적인 원인과 유전적인 원인이 모두 관여하는 질환으로 최 근 연구에 따르면 부모 중 한 사람이 아토피피부염 또는 천식, 알레르기성 비염이 있는 경우 자녀의 약 $40 \%$ 가 아토피피부염 이 발생 할 수 있으며 부모 모두가 병력이 있는 자녀의 경우 약 $70 \%$ 가 아토피피부염이 발생할 수 있다고 보고 되었다(Marsh 등, 1994). 아토피피부염의 주요증상은 소양증, 피부 건조증, 안 면 홍조 또는 창백, 전방 피막하 백내장, 원추 각막 등의 증상 등이 나타난다(Kim과 Pyun, 2002). 피부 병변의 분포는 환자의 연령, 유발물질과의 접촉 기간에 따라 다양하며 초기 병변은 얼 굴, 두피, 사지의 신전 부위에 주로 나타나며 만성화가 되면 사 지의 굴곡 부위로 주로 나타난다(Beltrani, 1999).

우슬(Achyranthis Radix)은 아시아지역에 광범위하게 분포하 는 다년초 식물인 쇠무릎(Achyranthes bidentata) 또는 우슬 (Achyranthes japonica)의 뿌리를 지칭하는 것으로 비름과 (Amaranthaceae)에 속한다. 한방에서 알려진 우슬의 약리작용으 로 부종, 진통작용, 혈압강하, 이뇨작용, 류머티스 등 면역반응 에 대한 민간요법으로 널리 사용하였다(Han 등, 2005; Bang 등, 2012). 우슬에는 항보체 효과를 갖는 oleanolic acid계 saponin 
이 소량 함유되어 있으며 oleanolic acid bisdesmoside, 3- $\beta$-Dglucopyranosyl-olean-12-en-28-O- $\beta$-D-glucopyranosyl ester가 분 리 보고 되었다(Jung 등, 2012). 그 외에 중추 미각계의 신호전 달을 억제하는 $\gamma$-aminobutyric acid 등이 알려져 있으며(Hahn과 Lee, 1991; Kim 등, 2005; Joycharat 등, 2013), 곤충 변태 호 르몬인 ecdysterone는 항산화 효과를 나타낸다고 알려져 있다 (Feng 등, 2012). 그 밖에 steroid 계열인 $\beta$-sitosterol, stigmasterol, stigmasterol glycoside, rubrosterone 등과 triterpenoid 계열의 inkosterone과 같은 화합물들이 보고 되어있다(Hahn과 Lee, 1991; Nakagawa 등, 1995).

본 연구는 화장품 소재로 활용 할 목적으로 열수추출 방법을 통해 우슬의 성분을 추출한 후 ultra-performance liquid chromatography (UPLC)와 연계한 유도 활성 분획법(active-guided fractionation)을 이용해 추출물로부터 분리한 3종의 phytoecdysones 성분에 대하여 염증반응에 관여하는 비만세포(RBL$2 \mathrm{H} 3$ cell)에서의 tumor necrosis factor (TNF)- $\alpha$ 억제 효과와 각 질형성세포 (HaCaT cell)에서의 아토피피부염의 타겟 표적으로 알려진 thymus and activation-regulated chemokine (TARC), macrophage-derived chemokine (MDC) 형성 억제 효과를 검정 함으로써 우슬의 추출물 및 단일 화합물들의 기능성화장품 소 재개발에 대한 가능성 연구를 수행하였다.

\section{재료 및 방법}

실험재료. 본 실험에 사용 된 우슬(Achyranthis Radix)은 2013 년 제주도에서 구매한 것으로, (주) 콧데(http://www.cotde.co.kr/) 에서 제공받아 사용하였다.

시약 및 기기. 분리에 사용된 high performance liquid chromatography (HPLC)용 $\mathrm{MeOH}$ 과 $n$-BuOH은 Wintech (Korea) 에서 구매하였으며 분획물의 분리에 사용된 Diaion HP-20은 Mitsubishi chemical corporation (Japan)에서 구매하였다. Preparative-HPLC는 Gilson, Inc., France 컬럼은 YMC-pack ODS AQ-HG $(20 \times 250 \mathrm{~mm}, 10 \mu \mathrm{m}$, Japan)을 UPLC는 Waters (Micromass UK Ltd., UK), high resolution electrospray ionization mass spectrometry (HRESIMS)는 Waters Q-TOF Premier mass spectrometer (Micromass UK Ltd., UK), NMR spectrum은 $400 \mathrm{MHz}$ FT-NMR spectrometer (Varian UNITY $400 \mathrm{NMR}$ system Varian, USA)로 ${ }^{1} \mathrm{H}-\mathrm{NMR}$ - $400 \mathrm{MHz},{ }^{13} \mathrm{C}-\mathrm{NMR}$ $100 \mathrm{MHz}$ 에서 측정하였다. $\mathrm{NMR}$ 용매는 pyridine- $d_{6}, \mathrm{CD}_{3} \mathrm{OD}$ (cambridge Isotope Laboratories, USA)를 사용하였다. 실험에 필요한 RBL-2H3과 $\mathrm{HaCaT}$ cell은 한국 세포주 은행(Korea Cell Line Bank)으로부터 구입하였으며 세포배양 위한 배지는 $1 \%$ antibiotic (Gibro, USA)와 10\% fetal bovine serum (FBS; Gibro, USA)이 함유된 Dullbecco's Modified Eagle's Medium (DMEM)를 사용하였다. HMC-1의 염증 유도 및 세포 생존율의 측정을 위한 phorbol-myrisrate acetate (PMA), calcium ionophore A23187, 3-(4,5-dimethylthiazol-2-yl)2,5-diphenyltetrazolium bromide (MTT)와 dimethlsulfoxide (DMSO)는 Sigma-Aldrich (USA) 제품을 사용하였다. Microplate reader는 SpectraMax M5 (Molecular Devises, USA)를 사용하였으며 실험에 필요한 모든 시약은 특급시약을 사용하였다.

우슬 추출물 및 분획물 제조. 우슬의 추출은 기능성 화장품 소재 개발에 있어서 추출물의 공정의 편의성을 위해 열수추출
방법을 통해 추출하였다. 건조된 우슬 $782 \mathrm{~g}$ 을 잘게 분쇄하여 증류수 $10 \mathrm{~L}$ 와 함께 $90^{\circ} \mathrm{C}$ 의 온도로 30 분간 진탕하여 열수 추 출하였다. 얻어진 추출물은 모두 감압 농축하여 열수 추출물 $(140.9 \mathrm{~g}, 18 \%)$ 을 얻었다. 얻어진 열수 추출물에 $\mathrm{H}_{2} \mathrm{O}$ 를 $2 \mathrm{~L}$ 을 가하여 현탁 시키고 동량의 $n-\mathrm{BuOH}(2 \mathrm{~L} \times 3)$ 을 넣어 $\mathrm{H}_{2} \mathrm{O}$ 층과 $n-\mathrm{BuOH}$ 층으로 분획 후 감압 농축하여 각각 $\mathrm{H}_{2} \mathrm{O}(17.5 \mathrm{~g})$ 과 $n$ $\mathrm{BuOH}(6.8 \mathrm{~g})$ 분획 층을 얻었다.

$n$-BuOH 분획물로부터 활성성분 분리. $n-\mathrm{BuOH}$ 분획물 $(6.8 \mathrm{~g})$ 을 Diaion HP-20 칼럼 $(5 \times 70 \mathrm{~cm}, \mathrm{MeOH}: \mathrm{DW}=0 \% \rightarrow 20 \% \rightarrow$ $40 \% \rightarrow 60 \% \rightarrow 80 \% \rightarrow 100 \%)$ 을 실시하여 총 6 개 분획물(Fr. 16)을 얻었다. 이들 중 TNF- $\alpha$ 저해 효과가 가장 강한 분획물 5 를 반복적으로 prep-HPLC (YMC-Pack ODS AQ-HG, 250×20 $\mathrm{mm}, 10 \mu \mathrm{m}$ )를 실시하였으며 $254 \mathrm{~nm}$ 파장에서 유도활성 분획 법(active-guided fractionation)을 이용하여 ecdysterone (1), 25S-inokosterone (2)와 25R-inokosterone (3) 화합물 3종을 분 리하였다.

UPLC-QTOF-MS 분석과 구조 동정. 분리된 성분의 질량분 석에는 UPLC-QTOF-MS은 $1.7 \mu \mathrm{m}, 2.1 \times 100 \mathrm{~mm}$, ACQUITY UPLC $\mathrm{C}_{18} \mathrm{BEH}$ column을 이용하여 분석을 수행하였으며 column은 $35^{\circ} \mathrm{C}$ 를 유지하였다. 유속은 $0.4 \mathrm{~mL} / \mathrm{min}$ 이며 $\mathrm{A}$ 용매 는 $0.1 \% \mathrm{D} . \mathrm{W}, \mathrm{B}$ 용매는 $0.1 \%$ acetonitrile를 이용하여 $0-1 \mathrm{~min}$ $10 \%$ B, 1-12 min 98\% B, 12-13.4 min 98\% B, 13.4-13.5 $\min 10 \% \mathrm{~B}$ 조건으로 흘렸으며 시료는 $2 \mu \mathrm{L}(1 \mathrm{mg} / \mathrm{mL})$ 주입 하였다. 분석에는 electron spray ionization (ESI) mode에서 negative로 수행하였다. 분리된 화합물 3 종은 ${ }^{1} \mathrm{H}-,{ }^{13} \mathrm{C}-\mathrm{NMR}$ 과 $2 \mathrm{D} \mathrm{NMR}$ 인 $\mathrm{COSY}, \mathrm{BMQC}, \mathrm{HMBC}$ 를 통해 구조분석 하였으 며, 이전의 참고문헌과 비교하여 구조분석 확인하였다(Rueda 등, 2014).

화합물 1 (ecdysterone): white amorphous powder; mp. 236$238^{\circ} \mathrm{C}$; UV $\lambda_{\max }(\mathrm{MeOH}) 242 \mathrm{~nm}$; HRESIMS $\mathrm{m} / \mathrm{z} 497.3007$ $[\mathrm{M}-\mathrm{H}]^{-} ;{ }^{1} \mathrm{H}-\mathrm{NMR}\left(400 \mathrm{MHz}, \mathrm{CD}_{3} \mathrm{OD}, \delta_{\mathrm{H}}\right): 62.5(1 \mathrm{H}, \mathrm{d}, J=2.2$ $\mathrm{Hz}, \mathrm{H}-7), 4.21(1 \mathrm{H}$, br. $\mathrm{s}, J=2.4 \mathrm{~Hz}, \mathrm{H}-3), 4.17(1 \mathrm{H}, \mathrm{m}$, $\mathrm{H}-2), 3.31$ (1H, d, $J=10.4 \mathrm{~Hz}, \mathrm{H}-22), 3.14$ (1H, m, H-9), $2.38(2 \mathrm{H}, \mathrm{m}, \mathrm{H}-17), 2.38(1 \mathrm{H}, \mathrm{m}, \mathrm{H}-5), 2.13(2 \mathrm{H}, \mathrm{m}, \mathrm{H}-$ 15b), 2.02 (2H, m, H-16b), 1.97 (2H, m, H-12b), 1.85 (2H, m, H-15a), 1.83 (2H, m, H-4b), 1.79 (2H, m, H-11b), 1.75 $(2 \mathrm{H}, \mathrm{m}, \mathrm{H}-16 \mathrm{a}, 24 \mathrm{~b}), 1.71(2 \mathrm{H}, \mathrm{m}, \mathrm{H}-1 \mathrm{~b}), 1.67(2 \mathrm{H}, \mathrm{m}$, $\mathrm{H}-11 \mathrm{a}), 1.66(2 \mathrm{H}, \mathrm{m}, \mathrm{H}-4 \mathrm{a}), 1.61(2 \mathrm{H}, \mathrm{m}, \mathrm{H}-12 \mathrm{a}), 1.42$ $(2 \mathrm{H}, \mathrm{m}, \mathrm{H}-1 \mathrm{a}), 1.28(2 \mathrm{H}, \mathrm{m}, \mathrm{H}-23 \mathrm{a}), 1.18(3 \mathrm{H}, \mathrm{s}, \mathrm{H}-26$, 27), 0.96 (3H, s, H-19), 0.89 (3H, s, H-18); ${ }^{13} \mathrm{C}-\mathrm{NMR}(100$ $\mathrm{MHz}, \mathrm{CD}_{3} \mathrm{OD}, \delta_{\mathrm{c}}$ ), 206.4 (C-6), 168.0 (C-8), 122.1 (C-7), 85.2 (C-14), 78.4 (C-22), 77.9 (C-20), 71.3 (C-25), 68.7 (C2), 68.5 (C-3), 51.7 (C-5), 50.5 (C-17), 48.8 (C-13), 42.4 (C-24), 39.3 (C-10), 37.3 (C-1), 35.1 (C-9), 33.0 (C-4), 32.5 (C-15), 31.7 (C-12), 29.7 (C-27), 29.0 (C-26), 27.3 (C23), 24.4 (C-19), 21.5 (C-11), 21.5 (C-21), 21.1 (C-16), 18.0 (C-18).

화합물 2 (25S-inokosterone): white amorphous powder; mp. $242-244^{\circ} \mathrm{C}$; UV $\lambda_{\max }(\mathrm{MeOH}) 242 \mathrm{~nm} ;$ HRESIMS $\mathrm{m} / z$ $497.3011[\mathrm{M}-\mathrm{H}]^{-} ;{ }^{1} \mathrm{H}-\mathrm{NMR}\left(400 \mathrm{MHz}\right.$, pyridine- $\left.d_{6}, \delta_{\mathrm{H}}\right): 6.26$ $(1 \mathrm{H}, \mathrm{d}, J=1.7 \mathrm{~Hz}, \mathrm{H}-7), 4.23(1 \mathrm{H}$, br. s, H-3), $4.18(1 \mathrm{H}$, m, H-2), $3.85(1 \mathrm{H}, \mathrm{d}, J=10.4 \mathrm{~Hz}, \mathrm{H}-22), 3.76(1 \mathrm{H}, \mathrm{dd}$, $J=10.0,5.2 \mathrm{~Hz}, \mathrm{H}-26 \mathrm{~b}), 3.64(1 \mathrm{H}, \mathrm{dd}, J=10.0,6.4 \mathrm{~Hz}, \mathrm{H}-$ 26a), 3.60 (1H, s, H-9), 2.95 (1H, t, $J=9.2 \mathrm{~Hz}, \mathrm{H}-17), 2.60$ 
(2H, m, H-15a), 2.46 (2H, m, H-16a), 2.17-2.24 (1H, m, H5), $2.17(2 \mathrm{H}, \mathrm{m}, \mathrm{H}-12 \mathrm{a}, 24 \mathrm{a}), 2.15(2 \mathrm{H}, \mathrm{m}, \mathrm{H}-1), 2.08(2 \mathrm{H}$, m, H-16b), 2.04 (2H, m, H-4a, 15b), 1.94 (2H, m, H-23a), $1.93(2 \mathrm{H}, \mathrm{m}, \mathrm{H}-1 \mathrm{~b}), 1.92$ (2H, m, H-12b), $1.88(2 \mathrm{H}, \mathrm{m}, \mathrm{H}-$ 11a), $1.82(2 \mathrm{H}, \mathrm{m}, \mathrm{H}-4 \mathrm{~b}), 1.81(1 \mathrm{H}, \mathrm{m}, \mathrm{H}-25), 1.73(2 \mathrm{H}, \mathrm{m}$, $\mathrm{H}-11 \mathrm{~b}), 1.63$ (2H, m, H-23b), $1.59(3 \mathrm{H}, \mathrm{s}, \mathrm{H}-21), 1.41(2 \mathrm{H}$, m, H-24b), 1.22 (3H, s, H-18), 1.07 (3H, s, H-19), 1.04 $(3 \mathrm{H}, \mathrm{d}, J=6.4 \mathrm{~Hz}, \mathrm{H}-27)$; ${ }^{13} \mathrm{C}-\mathrm{NMR}\left(100 \mathrm{MHz}\right.$, pyridine- $d_{6}$, $\delta_{\mathrm{c}}$ ), 203.7 (C-6), 166.4 (C-8), 121.9 (C-7), 84.2 (C-14), 77.3 (C-22), 76.8 (C-20), 69.0 (C-3), 68.1 (C-2), 67.4 (C-26), 51.4 (C-5), 50.1 (C-17), 48.2 (C-13), 38.7 (C-10), 38.1 (C-1), 36.8 (C-25), 34.5 (C-9), 32.5 (C-4), 32.1 (C-15, 24), 31.8 (C-12), 30.3 (C-23), 24.5 (C-19), 21.7 (C-21), 21.5 (C-16), 21.2 (C11), 17.9 (C-18), 17.8 (C-27).

화합물 3 (25R-inokosterone): white amorphous powder; mp. $242-244^{\circ} \mathrm{C}$; UV $\lambda_{\max }(\mathrm{MeOH}) 242 \mathrm{~nm}$; ESI-MS $\mathrm{m} / \mathrm{z}$ $497.3000[\mathrm{M}-\mathrm{H}]^{-}$; ${ }^{1} \mathrm{H}-\mathrm{NMR}$ (400 MHz, pyridine- $\left.d_{6}, \delta_{\mathrm{H}}\right): 6.26$ $(1 \mathrm{H}, \mathrm{d}, J=1.7 \mathrm{~Hz}, \mathrm{H}-7), 4.23(1 \mathrm{H}$, br. s, H-3 ), $4.18(1 \mathrm{H}$, $\mathrm{m}, \mathrm{H}-2), 3.85(1 \mathrm{H}, \mathrm{d}, J=10.4 \mathrm{~Hz}, \mathrm{H}-22), 3.76(1 \mathrm{H}, \mathrm{dd}$, $J=10.0,5.2 \mathrm{~Hz}, \mathrm{H}-26 \mathrm{~b}), 3.64$ (1H, dd, $J=10.0,6.4 \mathrm{~Hz}$, H-26a), 3.60 (1H, s, H-9), $3.01(2 \mathrm{H}, \mathrm{m}, \mathrm{H}-24 \mathrm{~b}), 2.95(1 \mathrm{H}$, $\mathrm{t}, J=9.2 \mathrm{~Hz}, \mathrm{H}-17), 2.60(2 \mathrm{H}, \mathrm{m}, \mathrm{H}-15 \mathrm{a}), 2.46(2 \mathrm{H}, \mathrm{m}$, H-16a), 2.48 (2H, m, H-24a) 2.17-2.24 (1H, m, H-5), 2.17 (2H, m, H-12a), 2.15 (2H, m, H-1), 2.08 (2H, m, 16b), $2.04(2 \mathrm{H}, \mathrm{m}, \mathrm{H}-4 \mathrm{a}, 15 \mathrm{~b}), 1.94(2 \mathrm{H}, \mathrm{m}, \mathrm{H}-23 \mathrm{a}), 1.93(2 \mathrm{H}$, m, H-1b), 1.92 (2H, m, H-12b), 1.88 (2H, m, H-11a), 1.82 $(2 \mathrm{H}, \mathrm{m}, \mathrm{H}-4 \mathrm{~b}), 1.81$ (1H, m, H-25), 1.73 (2H, m, H-11b), $1.63(2 \mathrm{H}, \mathrm{m}, \mathrm{H}-23 \mathrm{~b}), 1.59(3 \mathrm{H}, \mathrm{s}, \mathrm{H}-21), 1.22(3 \mathrm{H}, \mathrm{s}, \mathrm{H}-$ 18), 1.07 (3H, s, H-19), $1.04(3 \mathrm{H}, \mathrm{d}, J=6.4 \mathrm{~Hz}, \mathrm{H}-27)$; ${ }^{13} \mathrm{C}-\mathrm{NMR}\left(100 \mathrm{MHz}\right.$, pyridine- $\left.d_{6}, \delta_{\mathrm{c}}\right), 203.7$ (C-6), 166.4 (C8), 121.9 (C-7), 84.2 (C-14), 77.3 (C-22), 76.8 (C-20), 69.0 (C-3), 68.1 (C-2), 67.4 (C-26), $51.4 \quad(\mathrm{C}-5), 50.1 \quad$ (C-17), 48.2 (C-13), 38.7 (C-10), 38.1 (C-1), 36.8 (C-25), 34.5 (C9), 32.5 (C-4), 32.1 (C-15, 24), 31.8 (C-12), 30.3 (C-23), 24.5 (C-19), 21.7 (C-21), 21.5 (C-16), 21.2 (C-11), 17.9 (C18), 17.8 (C-27).

세포배양. 항 아토피 실험에서 사용한 human keratinocyte cell line인 $\mathrm{HaCaT}$ cell와 rat basophilic leukemia cell인 RBL-2H3 cell을 사용하였으며 배양 접시에 배양 후 $1 \%$ penicillin $(100$ $\mathrm{IU} / \mathrm{mL})$, streptomycin $(100 \mu \mathrm{g} / \mathrm{mL}), 10 \% \mathrm{FBS}$ 이 함유된 DMEM 배지를 넣고 $37^{\circ} \mathrm{C}, 5 \% \mathrm{CO}_{2}$ incubator에서 배양하였으며 4일에 한번씩 계대 배양을 하였다.

세포 중식률 및 독성 평가. 시료가 세포의 성장에 미치는 영 향을 측정하기 위하여 MTT assay를 진행 하였다. HaCaT cell 과 $\mathrm{BRL}-2 \mathrm{H} 3$ cell을 $1 \%$ antibiotic과 $10 \% \mathrm{FBS}$ 가 첨가된 $\mathrm{DMEM}$ 배지를 이용하여 각각 $3.0 \times 10^{5} \mathrm{cells} / \mathrm{mL}, 2.0 \times 10^{5}$ cells $/$ $\mathrm{mL}$ 로 96 well plate에 넣고 18시간 배양 후 시료를 처리하고 24시간 배양하였다. 이 후 MTT용액 $50 \mu \mathrm{L}$ 를 첨가하여 4시간 동안 반응 시켰다. 배양배지를 완전히 제거하고 $\mathrm{DMSO} 200 \mu \mathrm{L}$ 를 가하여 침전물을 완전히 용해시킨 후, microplate reader를 사용하여 $540 \mathrm{~nm}$ 흡광도를 측정하였다. 각 시료 군에 대한 평 균 흡광도 값을 구하였으며, 대조군의 흡광도 값과 비교하여 세 포성장률을 평가하였다. Proliferation Index $(\%)=$ 시료 흡광도 /control 흡광도 $\times 100$
TARC, MDC 생성 억제 활성 측정. $\mathrm{HaCaT}$ cell을 $3.0 \times 10^{5}$ cells $/ \mathrm{mL}$ 로 24 well plate에 심은 다음, 18 시간 동안 배양하고, IFN- $\gamma(10 \mu \mathrm{g} / \mathrm{mL})$ 와 TNF- $\alpha(10 \mu \mathrm{g} / \mathrm{mL})$ 시료 용액을 처리 후 24시간 배양한다(Sung 등, 2012). 이후 세포 배양 배지를 원심 분리하여 얻어진 상층액의 TARC, $\mathrm{MDC}$ 생합성량을 측정하였 다. 모든 시료는 정량 전까지 냉동보관 하였다. TARC, $\mathrm{MDC}$ 는 human enzyme-linked immnunosorbent assay (ELISA) kit (R\&D Systems, USA)를 이용하여 그 양을 측정하였다.

TNF- $\alpha$ 생성 억제 활성 측정. Mast cell인 RBL-2H3 cell을 $2.0 \times 10^{5}$ cells $/ \mathrm{mL}$ 의 밀도로 24 well plate에 심은 다음, 18 시 간 동안 배양하고, PMA $1 \mu \mathrm{g} / \mathrm{mL}$ 와 A23187 $1 \mu \mathrm{M}$ 시료용액 을 넣은 후 24 시간 배양한다(choi 등, 2012). 이후 세포 배양 배지를 원심 분리하여 얻어진 상층액의 TNF- $\alpha$ 합성량을 측 정 하였다. 모든 시료는 정량 전까지 냉동보관 하였다. TNF$\alpha$ 는 rat (ELISA) kit (R\&D System)를 이용하여 그 양을 측 정하였다.

\section{결과 및 고찰}

UPLC-based TNF- $\alpha$ 유도활성 분획. 열수 추출하여 얻어진 우슬 추출물 $(140.9 \mathrm{~g})$ 에 대하여 $n-\mathrm{BuOH}$ 으로 분획하고 그 중 $n$ $\mathrm{BuOH}$ 분획물을 Diaion column chromatography를 이용하여 $\mathrm{MeOH}$ 조건으로 순차적으로 $0 \% \rightarrow 20 \% \rightarrow 40 \% \rightarrow 60 \% \rightarrow$ $80 \% \rightarrow 100 \%$ 로 흘려 총 6 개의 분획물(Fr. 1-6)을 얻었다. 얻어 진 6 개의 분획물에 대한 UPLC 분석을 위해 $1.7 \mu \mathrm{m}, 2.1 \times 100$ $\mathrm{mm}$, ACQUITY UPLC $\mathrm{C}_{18} \mathrm{BEH}$ column을 수행하였다(Fig. $1 \mathrm{~A})$. 항 아토피 효과를 확인하기 앞서 RBL-2H3 cell의 세포독 성을 확인하기 위해 MTT assay를 이용하여 세포 생장률을 평 가하였다. 그 결과, 분획물 1,6 을 제외한 모든 분획물(Fr. 2-5) 에서 $100 \%$ 생존율을 나타내어 동일한 농도에서 항 아토피 효 과를 측정하였다(Fig. 1B). RBL-2H3 cells에서 분비되는 TNF$\alpha$ 의 저해활성을 측정한 결과, PMA 및 A23187을 처리한 실험 군에서 생성이 증가하였으며, 분획물(Fr. 1-6)을 함께 처리 했을 때 분획물 5 에서 가장 우수한 TNF- $\alpha$ 저해활성 효과를 나타내 었다(Fig. 1C). 분획물 5에서 유효 화합물들을 분리하고자 하였 으며 자세한 내용은 아래에 언급하였다.

$n$-BuOH 분획물로부터 활성성분 분리. 우슬 $n-\mathrm{BuOH}$ 분획물 에서 얻은 6 개의 분획물 중 $\mathrm{TNF}-\alpha$ 저해 활성이 가장 높은 분 획물 5 의 분리를 위해 prep-HPLC를 진행하였다. 분리하기 위해 prep-HPLC에 ODS column (YMC-pack ODS AQ-HG, 250 $\times 20 \mathrm{~mm}, 10 \mu \mathrm{m}$ )을 이용하여 용매 $\mathrm{A}$ 는 $\mathrm{H}_{2} \mathrm{O}, \mathrm{B}$ 용매는 $\mathrm{ACN}$ 을 이용하여 $0-10 \mathrm{~min} 15 \% \mathrm{~B}, 15-30 \mathrm{~min} 30 \%, 30-35 \mathrm{~min}$ $98 \% \mathrm{~B}, 35-40 \mathrm{~min} 25 \% \mathrm{~B}$ 용매조건으로 3종의 phytoecdysones 인 ecdysterone 1, 25S-inokosterone 2, 25R-inokosterone 3을 얻었다(Scheme 1).

Phytoecdysones 분리 및 구조 분석. 상기 분리한 화합물 3종 은 모두 HR-ESIMS에서 $\mathrm{m} / \mathrm{z} 479.3009[\mathrm{M}-\mathrm{H}]^{-}$의 분자 이온 peak을 나타내었으며 분자식은 3 종 모두 $\mathrm{C}_{27} \mathrm{H}_{44} \mathrm{O}_{7}$ 으로 확인되 어 fragments pattern이 동일하여 유사한 골격을 가지는 화합물 임을 확인 할 수 있었다(Fig. 2, Table 1). 분리된 화합물 3종은 $1 \mathrm{D} \mathrm{NMR}(1 \mathrm{H}, 13 \mathrm{C}, \mathrm{DEPT})$ 과 2D NMR (COSY, HMQC, $\mathrm{HMBC}$ ) 분석을 통하여 ecdysterone (1), 25S-inokosterone (2), 25R-inokosterone (3)임을 각각 구조 분석하였고 이전 참고 문 
(A)

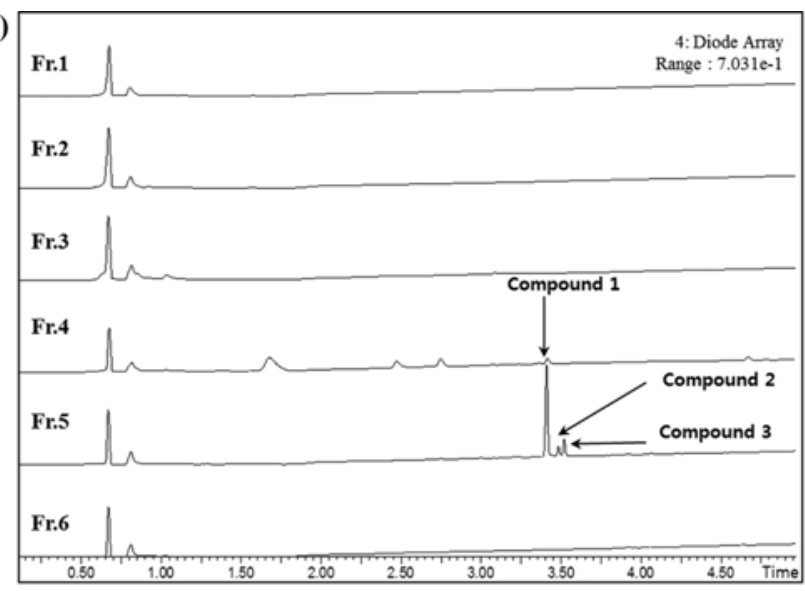

(B)

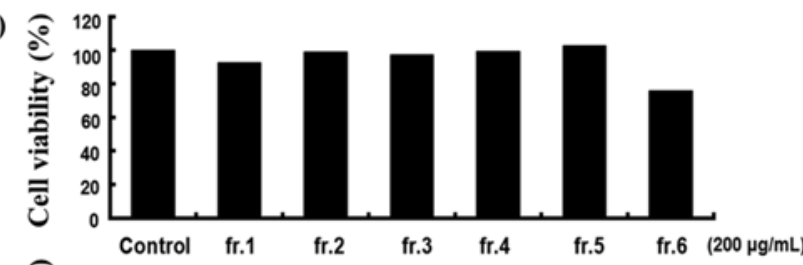

(C)

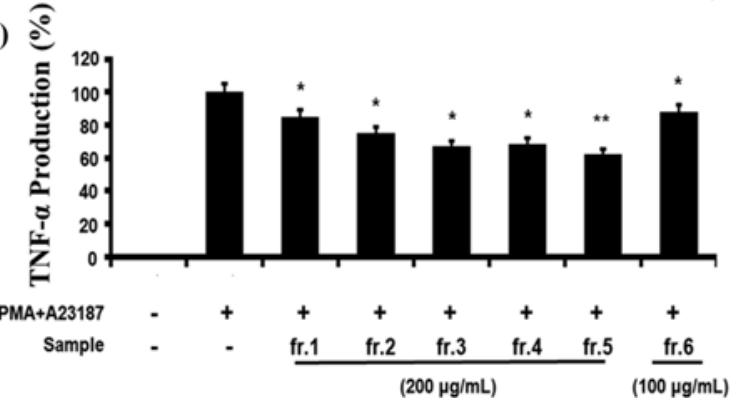

Fig. 1 UPLC-based inhibitory activity profiling of a fractions 1-6 from Achyranthes japonica Nakai (A), for cell viavility (B) and TNF- $\alpha$ expression levels (C) in A23187 plus PMA-induced RBL-2H3 cells. Cells were pretreated with fraction (Fr.1-5, $200 \mu \mathrm{g} / \mathrm{mL}$; Fr.6, $100 \mu \mathrm{g} / \mathrm{mL}$ ) for $1 \mathrm{~h}$ prior to PMA $(1 \mu \mathrm{g} / \mathrm{mL})+$ A23187 $(1 \mu \mathrm{M})$. Results expressed as the mean $\pm \mathrm{SD}$ of three independent experiments. ${ }^{*} p<0.005,{ }^{* *} p<0.001$ compared with co-treatment with A23187 and PMA.

헌과 비교하여 동일함을 확인하였다(Nakagawa 등, 1995 ; Balazs 등, 2013).

TNF- $\alpha$ 생성 억제. 비만세포는 세포질 내에 과립을 풍부하게 가지고 있는 세포로 과립내의 싸이토카인 등을 분비하면서 알 레르기 염증의 초기반응과 후기 반응을 일으킨다(Puxeddu 등, 2003). 알레르기 유발물질로 인해 활성화된 비만세포는 혈관확 장 물질인 histamine과 pro-inflammatory cytokine인 IL-3, IL-4 $\mathrm{IL}-5, \mathrm{IL}-6, \mathrm{IL}-8, \mathrm{TNF}-\alpha$ 등의 분비를 자극하며(Kim 등, 2013) 이 중 TNF- $\alpha$ 는 세포의 성장과 분화, 여러 cytokine의 생성과 괴사에 작용 함으로써 아토피피부염에 영향을 미친다(Baugh과 Bucala, 2001). 이번 실험에 사용된 RBL-2H3 cells은 결체조직 과 점막에 존재하면서 외부 자극에 의해 알레르기 염증반응을 일으키는 매개체를 생산 분비하는 것으로 알려져 있다(Choi 등, 2012). 분리된 3종의 화합물들에 대한 독성평가 결과 세포 생 존율이 $95 \%$ 이상임을 확인 하였으며(Fig. $3 \mathrm{~A}$ ), 동일 농도에서 3 종의 화합물들에 대한 TNF- $\alpha$ 효과를 측정한 결과, 화합물 2

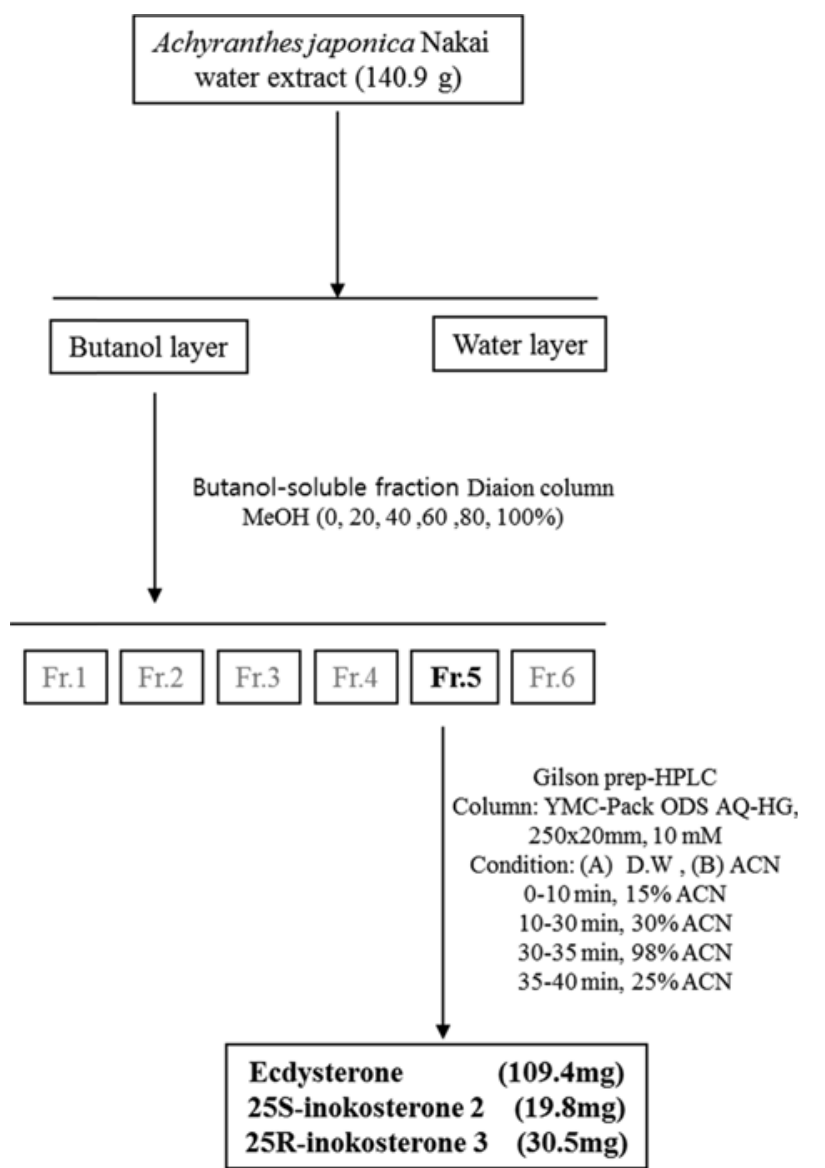

Scheme 1 Schematic diagram illustrating the fractionation and isolation of compounds1-3 from Achyranthes japonica Nakai roots.

는 $80 \%$ 정도 저해활성을 나타내었으며 화합물 1 과 3 은 $90-$ $95 \%$ 의 매우 우수한 TNF- $\alpha$ 저해활성이 확인되었다(Fig. $3 \mathrm{~B})$. 우 슬의 활성분획에서 분리된 단일성분들은 이전 연구를 통해 상 업적으로 활용 가능한 luteolin과 비교할 때 TNF- $\alpha$ 생성 억제 효과가 $10 \%$ 이상 더 높은 것으로 확인되어 우수한 항염증 효과 가 있음을 확인 할 수 있었다(Chen 등, 2010; Choi 등, 2010). TARC 및 MDC 생성 억제. 아토피피부염은 피부에서 발생하 는 면역학적 질환으로 알레르기 면역반응의 표적인 각질형성세 포를 자극하여 발생한다. 각질형성세포에 존재하는 thymic stromal lymohopo (TSLP)는 포유류의 면역계를 구성하는 수지 상세포를 자극해서 $\mathrm{TARC}$ 와 $\mathrm{MDC}$ 생성을 증가 시키는데 이러 한 chemokine의 농도는 아토피피부염의 증상과 밀접한 연관성 을 가지고 있다고 알려져 있다(Soumelis 등, 2002). 그러므로 $\mathrm{TARC}$ 와 $\mathrm{MDC}$ 의 발현을 유도한 각질형성세포에 감소량을 측정 하여 아토피 억제 효능을 확인 할 수 있다(Lee 등, 2011; Kwon 등, 2012). 항 아토피 매개 물질에 대한 실험을 하기에 앞서 세포독성을 확인하기 위해 동일농도 $(200 \mu \mathrm{g} / \mathrm{mL})$ 에서 MTT assay를 이용하여 $\mathrm{HaCaT}$ cells의 세포 생존율을 평가한 결과 3 종 화합물 모두 $98 \%$ 이상 세포생존율을 나타내 독성이 없음을 확인하였다(Fig. 4A). 항 아토피 효능 평가로서는 각질 형성 세포인 $\mathrm{HaCaT}$ cell에 IFN- $\gamma$ 및 TNF- $\alpha$ 처리를 통하여 $\mathrm{TARC}$ 와 $\mathrm{MDC}$ 의 생성을 확인하였고 분리된 화합물 3 종을 처 
(A)

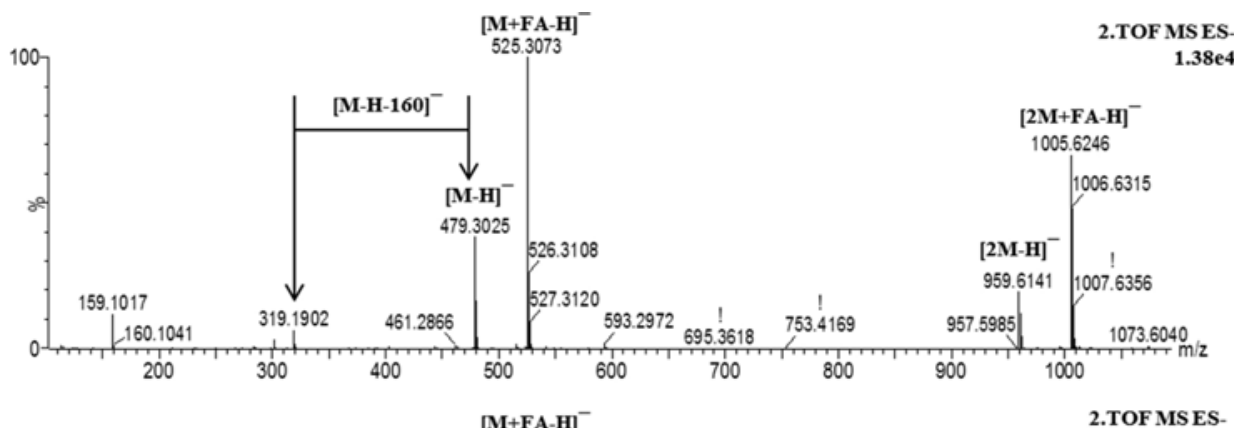

MSES

Ecdysterone

(B)
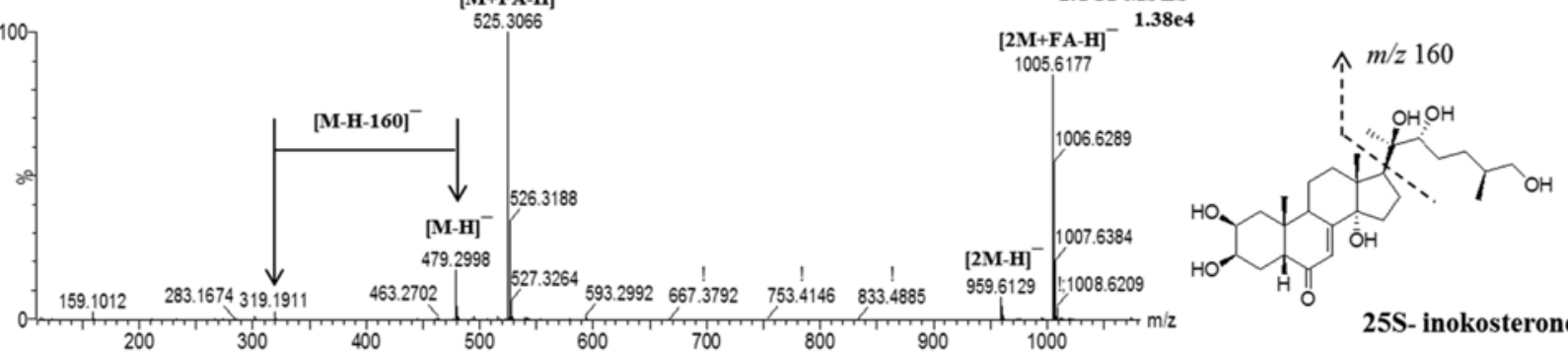

(C)

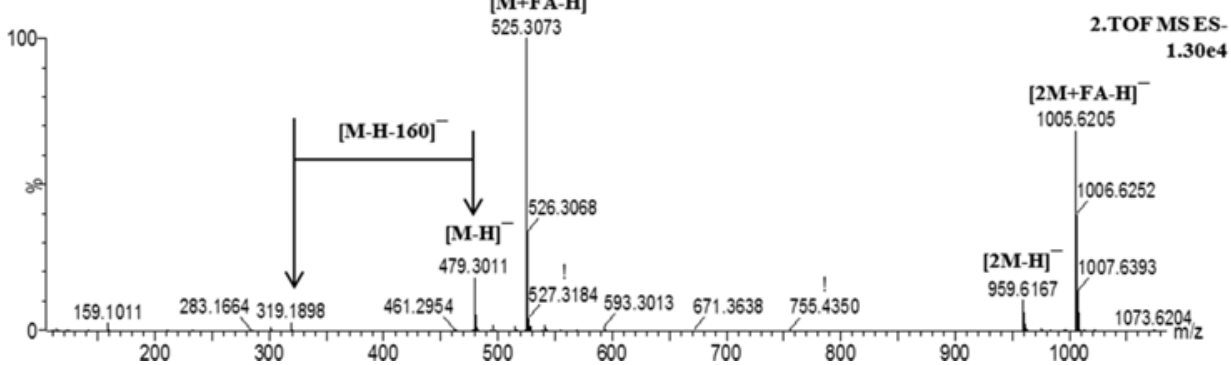

25S- inokosterone

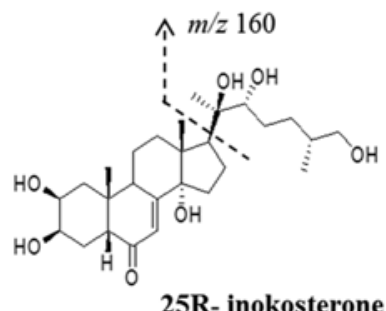

Fig. 2 Mass fragmentation patterns of isolated compounds 1-3 from Achyranthes japonica Nakai. (A) ecdysterone (1); (B) 25S-inokosterone (2); (C) 25R-inokosterone (3).

Table 1 UPLC chromatogrphic, mass spectral and UV-Vis data of phytoecdysones in Achyranthes japonica Nakai

\begin{tabular}{ccccccccc}
\hline Comp. & $\begin{array}{c}\text { UPLC } t_{R} \\
(\mathrm{~min})\end{array}$ & $\begin{array}{c}\text { Calculated } \\
{[\mathrm{M}-\mathrm{H}]^{-}}\end{array}$ & $\begin{array}{c}\text { Detected precursor } \\
\text { ion and/or adduct ions }\end{array}$ & $\begin{array}{c}\text { Error } \\
(\mathrm{ppm})\end{array}$ & $\begin{array}{c}\text { Molecular } \\
\text { formula }\end{array}$ & MS/MS & $\begin{array}{c}\text { UV-vis } \\
\text { Maxima (nm) }\end{array}$ & Identification \\
\hline 1 & 3.40 & 479.3009 & 479.3018 & 1.9 & $\mathrm{C}_{27} \mathrm{H}_{43} \mathrm{O}_{7}$ & 319 & 246 & ecdysterone \\
2 & 3.48 & 479.3009 & 479.2999 & -1.0 & $\mathrm{C}_{27} \mathrm{H}_{43} \mathrm{O}_{7}$ & 319 & 246 & $25 \mathrm{~S}$-inokosterone \\
3 & 3.52 & 479.3009 & 479.3022 & 2.7 & $\mathrm{C}_{27} \mathrm{H}_{43} \mathrm{O}_{7}$ & 319 & 246 & $25 \mathrm{R}$-inokosterone \\
\hline
\end{tabular}

리하여 24시간 배양 후 $\mathrm{TARC}$ 와 $\mathrm{MDC}$ 의 생성 억제 측정 하였 다. 그 결과 ecdysterone (1)은 저해활성이 나타나지 않았으며 25S-inokosterone (2)와 25R-inokosteron (3)은 각각 $51 \%$ 와 $23 \%$ 의 TARC 발현이 억제하는 것으로 나타났다(Fig. 4B). 한편, $\mathrm{MDC}$ 에서는 억제 효과가 크게 나타나지 않았다(Fig. 4C). 구조 활성 상관관계를 확인한 결과 기본골격에 alkyl 치환기의 형태 에 따라 활성의 양상이 달라졌으며, 특히 25S-inkosterone (2)와 25R-inkosterone (3)는 치환기의 stereo에 따라 저해 활성의 차 이가 나타났다. 기존 연구에서 아토피피부염의 효과를 확인 한 팔각회향(Illicium verum)과 TARC 생성 억제 효과를 비교 하였 을 때 유사한 효과를 나타내었다(Sung 등, 2012) 이상의 결과 를 종합해 보면 우슬의 추출물과 분획물에서 분리한 화합물들 이 천연기능성 화장품 원료로서의 응용 가능성을 확인 할 수 있었다.

\section{초 록}

본 연구에서는 우슬 열수 추출물을 $n-\mathrm{BuOH}$ 과 $\mathrm{H}_{2} \mathrm{O}$ 로 용매 분 획 한 후 $n-\mathrm{BuOH}$ 분획물을 컬럼 크로마토그래피를 수행하여 6 개의 소분획물(Fr. 1-6)을 얻었다. 소분획물 6개에 대해 tumor necrosis factor (TNF)- $\alpha$ 저해활성 검정을 통하여 가장 높은 활 성을 나타낸 분획물 5 에서 preparative-high performance liquid chromatography를 이용해 3종의 phytoecdysone계열 화합물들을 분리하였다. 분리된 화합물들은 $\mathrm{NMR}$ 및 $\mathrm{MS}$ 분석을 통해 ecdysterone (1), 25S-inokosteron (2), 25R-inokosteron (3)임을 동정 하였고, 이들의 활성은 TNF- $\alpha$ 생산 저해활성은 $200 \mu \mathrm{g} /$ $\mathrm{mL}$ 에서 80-95\%의 $\mathrm{TNF}-\alpha$ 저해활성을 나타내었다. 또한 각질 형성 세포에 분리한 3종의 화합물을 처리한 결과 각각 51와 $23 \%$ 이상의 TARC의 생성 억제 효과를 확인 할 수 있었다. 이 


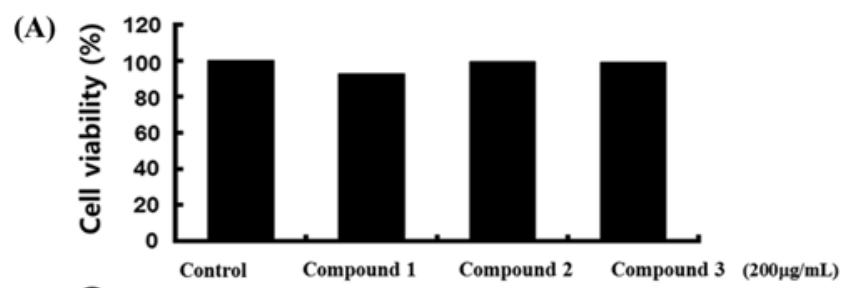

(B)

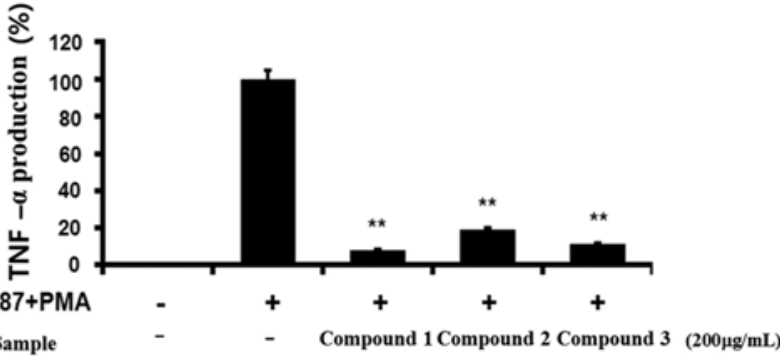

Fig. 3 Effect of isolated compounds 1-3 of Achyranthes japonica Nakai on cell viability (A) and TNF- $\alpha$ expression levels (B) in A23187 plus PMA-induced RBL-2H3 cells. Cells were pretreated with compounds 1-3 $(200 \mu \mathrm{g} / \mathrm{mL}$ for $1 \mathrm{~h}$ prior to PMA $(1 \mu \mathrm{g} / \mathrm{mL})+\mathrm{A} 23187(1 \mu \mathrm{M})$. Results expressed as the mean $\pm \mathrm{SD}$ of three independent experiments. ${ }^{*} p<0.005$, $* * p<0.001$ compared with co-treatment with A23187 and PMA.

(A)

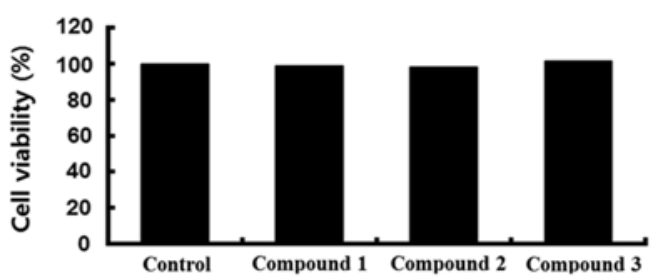

(B)
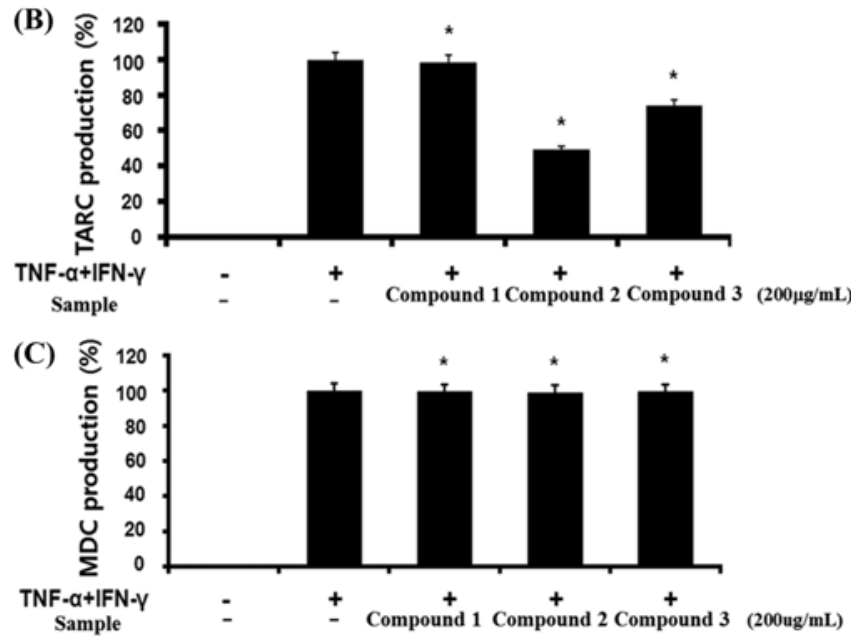

Fig. 4 Effect of isolated compounds 1-3 of Achyranthes japonica Nakai on cell viability (A) and TARC (B) MDC expression levels (C) in TNF$\alpha$ plus IFN- $\gamma$ induced HaCaT cells. Cells were pretreated with compounds 1-3 $(200 \mu \mathrm{g} / \mathrm{mL})$ for $1 \mathrm{~h}$ prior to TNF- $\alpha(10 \mu \mathrm{g} / \mathrm{mL})+\mathrm{IFN}-\gamma$ $(10 \mu \mathrm{g} / \mathrm{mL})$. Results expressed as the mean \pm SD of three independent experiments. ${ }^{*} p<0.005,{ }^{*} p<0.001$ compared with co-treatment with TNF- $\alpha$ and IFN- $\gamma$.

들의 결과로써, 우슬 추출물과 분리된 화합물들에 대한 항 아 토피 활성 결과로 천연물 기능성 식품 또는 화장품으로의 응용 가능성이 높다고 사료된다.
Keywords 아토피 · 우슬 · 항 - phytoecdysones

감사의 글 본 논문은 산업통상자원부의 2012년 제주권 광역경제권 선도산 업의 지원을 받아 수행된 것임(과제번호 R0001465).

\section{References}

Balazs A, Hunyadi A, Csabi J, Jedlinszki N, Martins A, Simon A et al. (2013) ${ }^{1} \mathrm{H}$ and ${ }^{13} \mathrm{C}$ NMR investigation of 20 -hydroxyecdysone dioxolane derivatives, a novel group of MDR modulator agents. Magn Reson Chem 51, $830-6$.

Bang SY, Kim JH, Kim HY, Lee YJ, Park SY, Lee SJ et al. (2012) Achyranthes japonica exhibits anti-inflammatory effect via NF- $\mathrm{BB}$ suppression and HO-1 induction in macrophages. $J$ Ethnopharmacol 144, 109-17.

Baugh HA and Bucala R (2001) Mechanisms for modulating TNF $\alpha$ in immune and inflammatory disease. Curr Opin Drug Disc 4, 635-50.

Beltrani VS (1999) The clinical spectrum of atopic dermatitis. J Allergy Clin Immun 104, 87-98.

Chen HJ, Shin CK, Hsu HY, and Chiang W (2010) Mast cell-dependent allergic responses are inhibited by ethanolic extract of adlay (Coix lachrymal-jobi L.var.ma-yuen stapf) testa. J agric food chem 58, 2596601.

Choi MJ, Lee YM, Jin BS, and Kim BH (2010) Inhibition effect Luteolin liposome solution by animal model for atopic dermatitis in $\mathrm{NC} / \mathrm{Nga}$ mice. Lab Animal Res 26, 47-53.

Choi Y, Kim MS, and Hwang JK (2012) Inhibitory effects of panduration A on allergy-related mediator production in Rat Basophilic Leukemia Mast cell. Inflammation 35, 1904-15.

Feng CY, Huang XR, Qi MX, Tang SW, Chen S, Hu YH et al. (2012) Mitochondrial proteomic analysis of ecdysterone protection against oxidative damage in human lens epithelial cells. Int J Ophthalmol Chi 7, $38-43$.

Hahn DR and Lee MW (1991) Studies on the constituents of Achranthis Radix (I). J Parm Soc Korea 35, 457-60.

Han SB, Lee CW, Yoon YD, Kang JS, Lee KH, Yoon WK et al. (2005) Precention of arthritic inflaamtion using an oriental herbal combination BDX-1 isolated from Achyranthes bidentata and Atractylodes japonica. Arch Pharm Res 28, 902-8.

Joycharat N, hammavong S, Limsuwan S, Homlaead S, Voravuthikunchai SP, Yingyongnarongkul BE et al. (2013) Antibacterial substances fraom Albizia myriophylla wood against cariogenic streptococcus mutans. Arch Pharm Res 36, 723-30.

Jung S, Lee S, Lee YC, and Moon HI (2012) Inhibitory effects of three Oleanolic acid glycosides from Achyranthes japonica on the complement classical pathway. Immunopharm Immunot 34, 213-5.

Kim HH, Bae YJ, and Kim SH (2013) Galangin attenuates mast cell-midiated allergic inflammation. Food chem Toxicol 57, 209-16.

Kim JW and Pyun BY (2002) Asthma and allergic diseases, (1st ed.), Koonja press, Korea.

Kim MW, Park HO, Pahng MS, Park SW, Kim SH, Kim SH et al. (2005) effect of Gamma-Aminobutyric Acid on the gustatory nucleus tractus solitaries in rats. Int J Oral Biol 30, 91-8.

Kwon DJ, Bae YS, Ju SM, Goh AR, Youn GS, Choi SY et al. (2012) Causuarinin suppresses TARC/CCL17 and MDC/CCL22 productiion via blockade of NF-kB and STAT1 acticvation in HaCaT cells. Biochem Bioph Res Co 417, 1254-9.

Lee KH, Cho YL, Joo CG, Joo YJ, Kwon SS, Ahn SM et al. (2011) Study on the antioxidative activities and anti-Inflammatory effect of Kaemferol and Kaempferol Rhamnosides. J Soc Cosmet Korea 37, 257-64.

Marsh DG, Neely JD, Breazeale DR, Ghosh B, Freidhoff LR, EhrlichKautzky E et al. (1994) Linkage analysis of IL-4 and other chromosome $5 \mathrm{q} 31.1$ markers and total serum immunoglobulin E concentrations. Science 264, 1152-6.

Nakagawa Y, Nishimura K, Oikawa N, Kurihara N, and Ueno T (1995) Activity of ecdysone analogs in enhancing $\mathrm{N}$-acetylglucosamine incor- 
poration into the cultured integument of Chilo suppressalis. Steroid $\mathbf{6 0}$, 401-5.

Park YL and Park J (2007) Pathogenesis of atopic dermatitis. J Invest Dermatol 14, 67-72.

Puxeddu I, Piliponsky AM, Bachelet I, and Levi-Schaffer F (2003) Mast cells in allergy and beyond. Int J Biochem Cell Biol 35, 1601-7.

Rueda DC, Mieri MD, Hering S, and Hamburger M (2014) HPLC-based activity profiling for $\mathrm{GABA}_{\mathrm{A}}$ receptor modulators in Adeno carpuscincinatus. J. Nat Prod 77, 640-9.
Soumelis V, Reche PA, and Kanzler H (2002) Human epithelial cell trigger dendritic cell mediated allergic inflammation by producing TSLP. Nat Immunol 3, 673-80.

Sung YY, Kim YS, and Kim HK (2012) Illicium verum extract inhibits TNF$\alpha$ and IFN- $\gamma$-induced expression of chemokines and cytokines in human keratinocytes. J Ethnopharmacol 144, 182-9.

Wollenberg A, Kraft S, Oppel T, and Bieber T (2000) Atopic dermatitis : pathogenetic mechanisms. Clin exp dermatol 25, 530-4. 